\title{
Evaluation of In Vitro Germination and Callus Induction for Antimicrobial Activities of Jatropha curcas $L$.
}

\author{
Manal S. Soliman ${ }^{1}$, Khallil Elhalafawi ${ }^{2}$, Ibrahim A. Ibrahim ${ }^{1}$, Emad Mahrous ${ }^{1}$ and Metwally \\ Bekhit $^{{ }^{*}}$ \\ 1 Plant Biotechnology Dept. Genetic Engineering and Biotechnology Research Institute (GEBRI), \\ University of Sadat City, Minufiya, Egypt. \\ ${ }^{2}$ Molecular Biology Dept. Genetic Engineering and Biotechnology Research Institute (GEBRI), \\ University of Sadat City, Minufiya, Egypt. \\ *Corresponding author: E-mail: Metwally.bekhit@gebri.usc.edu.eg
}

\begin{abstract}
There are many problems related to seed germination and in vitro cultivation of Jatropha curcas $\mathrm{L}$, this research was to solve this obstacle. This study also aimed to use triphenyl tetrazolium chloride (TTC) as a new substance for in vitro callus initiation and growth in plant tissue culture fields for the first time. In addition, an efficient regeneration method via seed culture has been developed. For this purpose, different media (MS; B5; WPM with B5 vitamins; wetted cotton and water) were used for seed germination. High seed germination percentage for all treatments were achieved after 24 days from incubation. WPM was effective medium in increasing the total length of seedlings. The maximum dry weight $(0.24 \mathrm{~g})$ of Jatropha curcas shoots was recorded with B5 medium. In vitro shoot formation, MS medium supplanted with $2.0 \mu \mathrm{M}$ IBA +10 $\mu \mathrm{M}$ BA and MS medium+2.5 $\mu \mathrm{M}$ BA+2.5 $\mu \mathrm{M}$ NAA recorded the highest shoot formation percentage (100\%) after one month. Concerning callus induction, data implied that different growth regulators tested (TDZ, BA, KIN) and TTC as a new substance used in plant tissue culture could induce the formation of callus in cotyledons of $J$. curcas seedlings, furthermore, the combination of BA and Kin in various concentrations was an appropriate medium for inducing the formation of callus and promoting its growth. Also, callus formation and growth were significantly affected by explant types. The balance between auxin and cytokinin is the limited factor for callus induction. MS nutrient medium supplemented with 2,4-D or NAA or both helped to form callus at high percentage. regarding antimicrobial activity, the antimicrobial potential of different plant extracts was screened against four pathogenic microorganisms and reference bacterial strains, the ethanolic extract of the roots was found to show greater inhibition of $B$. cereus and $E$. coli with zones of inhibition, 21.7 and $10.4 \mathrm{~mm}$ respectively, when comparing the extracts from in vivo plant and in vitro callus. Also, ethanol extract from the leaf of the mother plant showed higher inhibitory zone than that of the leaf-derived callus against S. aureus, B. cereus and E. coli. On the other hand, butanol extract of hypocotyl-derived callus was achieved the highest fraction effect resulted from different fractionation of crude methanolic extract against antibacterial activity of $E$. coli, followed by ethyl acetate- fraction (15.0 and $13.5 \mathrm{~mm}$ ) respectively, in contrast, water-fraction came in the last.
\end{abstract}

Keywords: Jatropha curcas; Auxin; Cytokinin; germination; Tissue culture; Nutrient medium, thidiazuron; triphenyl tetrazolium chloride; antimicrobial activity. 
Abbreviations: BA, 6- Benzyl adenine; IBA, indole-3-butyric acid; NAA, a-Naphthalene Acetic Acid 2,4-D, 2,4-dichlorophenoxy-acetic acid; MS, Murashige and Skoog; WPM, Woody Plant Medium; B5, Gamborg medium TDZ, thidiazuron, TTC triphenyl tetrazolium chloride. LB, Luria-Bertani medium.

\section{INTRODUCTION}

Jatropha curcas, belonging to Euphorbiaceae family, is a perennial, deciduous and oil-bearing shrub. The plant is monoecious with male and female flowers produced in the same raceme (Raju and Ezradanam, 2002). Jatropha carcas is a wild growing plant well adapted to conditions of soil and climate. It is also recommended as a drought resistant plant suitable for erosion control and is not palatable to grazing animals due to the toxicity (Mawahib et al., 2012). Moreover, it can conventionally propagate from seeds as well as branch cuttings. Conventional propagation through seeds is not reliable due to poor germination rate, heterozygosity, difficult in obtaining genetic uniformity, heterozygosity affects the quality of oil content. Jatropha curcas is one of the most valuable crude drugs of primitive times and is still widely used in modern medicine. It has multipurpose plant valued not only for its medicinal properties and resistant to various stresses but also for its use as an oil seed crop. Since, it is considered an important energy plant (ZhongGuang Li et al., 2012), the high yield of seed and the high oil content attracted global attention for the development of $J$. curcas as a source for biofuel (Openshow 2000, Adebowale and Adedire 2006; Li et al., 2007). Also, various parts of this plant were found to be rich in chemicals like organic acids, saponins, tannins, curcin, amyrin, phytase and sitosterol (Gandhi, et al., 1995, and Heller,
1996). The plant having high medicinal importance for curing various disorders. The oil is not edible due to the presence of toxic substance" Curcascine" (Gandhi, et al., 1995). In addition, J. curcas is also widely used as folk medicine, fertilizer, manufacturing of soap and candles, illumination, fish poison, inhibitor of watermelon mosaic virus, and nuts collected from a non-toxic Mexican variety are roasted and consumed (Modi et al., 2006; Carels, 2009; Bisen et al., 2010; Mukherjee et al., 2011).

In recent years this plant has received extensive attention of many scientists in view of its great economic importance, medicinal significant and for its seed oil as commercial source of fuel. Today, Jatropha curcas has gained much attention for both non-oil producers and oil producers' countries around the world. Nowadays focus is being placed on $J$. curcas plant uses and its effects in various fields. In this concern, different studies were carried out for callus formation and regeneration. Callus formation is central to many investigative and applied tissue culture procedures. Callus can be multiplied and later used to clone numerous whole plants. Since extensive callus formation can be induced by elevated hormone levels, tissue culture media designed to produce callus contain pharmacological additions of cytokinins and auxins. Callus cultures can also be used to initiate cell suspensions, which are used in a 
variety of ways in plant transformation studies. Additionally, various genetic engineering protocols employ callus initiation procedures after DNA has been inserted into cells; transgenic plants are then regenerated from transformed callus. Callus cultures were affected by a lot of factors, of them related to external environment conditions, medium compositions and plant materials used. Growth regulators are critical factors for formation of callus, as well as other medium components.

In this study we attempt to use a new substance namely Triphenyl tetrazolium chloride, (TTC) for first time in tissue culture field. Triphenyl tetrazolium chloride, TTC, or simply tetrazolium chloride (with the formula 2,3,5-triphenyl-2H-tetrazolium chloride) is a redox indicator commonly used in biochemical experiments especially to indicate cellular respiration and TTC assay as also known as TTC test or tetrazolium test to differentiate between metabolically active and inactive tissues. It is a white crystalline powder, soluble in water, ethanol and acetone but insoluble in ether (Witty, 2012). Tetrazolium salt stains all living tissue in the seed embryo red, thus enabling trained analysts to determine the seeds viability or otherwise. The tetrazolium test is used to give a quick estimate of germination potential. The result of a tetrazolium test will generally predict the germination test result closely, however the tetrazolium test will not detect certain types of abnormalities nor will it give any indication of disease levels, chemical damage or dormancy.

A vast number of medicinal plants have been recognized as valuable resources of natural antimicrobial compounds as an alternative that can potentially be effective in the treatment of these problematic bacterial infections. According to the World Health Organization (WHO), medicinal plants would be the best source to obtain a variety of drugs (Ruberto, et al., 2000). Plants are prospective source of antimicrobial agents in different countries (Alviano and Alviano, 2009). About 60 to $90 \%$ of populations in the developing countries use plant-derived medicine. Traditionally, crude plant extracts are used as herbal medicine for the treatment of human infectious diseases (Maliani, et al.,2013). Plants are rich in a variety of phytochemicals including tannins, terpenoids, alkaloids, and flavonoids which have been found in vitro to have antimicrobial properties (Talib and Mahasnh, 2010). Although the mechanism of action and efficacy of these herbal extracts in most cases is still needed to be validated scientifically, these preparations mediate important host responses. Global prevalence of infectious diseases caused by bacteria is a major public health problem (Paterson, 2008). The bacterial agents including Staphylococcus aureus, Escherichia coli, Bacillus subtilis, and Bacillus cereus cause several human infections (Periano, 2008). Recent emergence of antibiotic resistance and related toxicity issues limit the use of antimicrobial agents (Eggleston, et al., 2010) and is prompting a revival in research of the antimicrobial role of plants against resistant strains due to comparable safety and efficacy

The aim of this work is to improve seed germination and in vitro cultivation of Jatropha curcas as biodiesel production and pharmaceutical medicinal plants This study also, aimed to use triphenyl tetrazolium chloride (TTC) as a new substance for in vitro callus initiation and growth in plant tissue 
culture fields for the first time besides plant growth regulators in various levels. Also, the present paper is to contribute to the knowledge of Jatropha curcas cultivation through the presentation of preliminary results of different studies that are being carried out. In addition, it also aimed to produce callus from different explants in vitro seedling-derived for study the effect of crude extracts from cotyledonary leaf, hypocotyl, node and petiole callus, as well as, in vivo plant parts (leaf, stem, root and fruits), on antibacterial activity of bioactive compounds of Jatropha curcas L.

\section{MATERIALS AND METHOD}

\section{Plant Material}

Seeds of physic nut (Jatropha curcas L.) used in this study were obtained from the plants, growing in the farm of Genetic Engineering and Biotechnology Research Institute (GEBRI), University of Sadat City, Egypt. The plants and seeds were healthy and free of symptoms of disease and pest problems, showed good biomass yield and were used as the source of explants.

\section{Preparation of the explant}

Jatropha curcas seeds were used as the plant material. After removing the outer seed coat, sterilized by shaken for 30 min with $100 \%$ Clorox solution (containing $5.25 \%$ sodium hypochlorite), followed by three washes in sterilized distilled water, disinfectant seeds were pressed to open the cotyledons and then aseptically germinated in glass jars ( ca. $350 \mathrm{ml}$ ) containing $50 \mathrm{ml}$ of the following nutrient media, MS (Murashige and Skoog, 1962) basal medium; B5 (Gamborg et al., 1968) basal medium; Woody plant medium (WPM) (Lloyd G, McCown B., (1980) with B5 vitamins; as well as, sterilized wetted cotton and sterilized distilled water. Nutrient tissue culture media namely, MS, B5 and WPM media were supplemented with $3 \%$ sucrose and $7.0 \mathrm{~g} / \mathrm{l}$ agar without growth regulators. The $\mathrm{pH}$ value of media was set to $5.8 \pm 0.02$ before adding agar and these jars were then autoclaved at $121^{\circ} \mathrm{C}$ for 20 minutes at 15 psi and stored at incubation room for four days. According to the results of the previous experiment, wetted cotton used to germinate jatropha seeds. Seeds were then cultured under aseptic conditions, every jar has nine seeds and replicated thrice. All cultures were kept in the incubation room under complete darkness at $26 \pm 2{ }^{\circ} \mathrm{C}$ for 5 days and then exposure to 1000 lux light intensity provided by cool white fluorescent lamp for 8 hours dark and 16 hours light photoperiod daily for 24 days. Data were recorded at different four intervals as, seed germination \%, leaf numbers/shoot, shoot length, root numbers/shoot, root length, and fresh and dry weight of seedling at the end of incubation period. The percentage germination was calculated using the following formula;

Germination \% =№ of seeds germinated / Total № of seeds cultured $x 100$

\section{Callus initiation}

Several experiments were designed and carried out after seed germination for callus initiation and growth as the following for anti-microbial activities assay.

Cotyledonary leaves explants obtained from $15-17$ day-old seedlings grown in vitro were used as initial explants for callus 
induction. The explants were cultured on B5 medium supplemented with $3 \%$ sucrose and various concentrations of $B A, T D Z, T T C$, and $\mathrm{KIN}$ at concentrations of, 2.5, 5.0, 7.5 and 10 $\mu \mathrm{M}$ separately, as well as control treatment. All previous nutrient media were supplemented with $30 \mathrm{~g} / \mathrm{l}$ sucrose and $7 \mathrm{~g} / \mathrm{l}$ agar. The $\mathrm{pH}$ value of all media was adjusted to $5.7 \pm 0.1$ prior to autoclaving at $121^{\circ} \mathrm{C}$ at $1.1 \mathrm{~kg} / \mathrm{cm}^{2}$ for 15 minutes. Cultures were incubated under $16 \mathrm{~h} / 8 \mathrm{~h} \mathrm{light/dark}$ cycles at $26 \pm 2^{\circ} \mathrm{C}$ from cool light fluorescent lamps. All cultures were incubated for 35 days and data were recorded as callus formation \%, Callus fresh \& dry weight, and visual observation as well.

Cotyledonary leaves, hypocotyl, and cotyledon nodes explants were isolated from seedlings, and then sectioned into segments with length $0.5 \mathrm{~cm}$ or $1 \mathrm{~cm}^{2}$ and cultured on MS (Murashige and Skoog, 1962) basal solid medium supplemented with the following different plant growth regulators at various levels for callus induction and growth, as follow; $\mathrm{T} 1,(0.5 \mu \mathrm{M}$ of $2,4-\mathrm{D}+2.5 \mu \mathrm{M}$ of $\mathrm{KIN}+15.0 \mu \mathrm{M}$ of NAA), T2, $(2.0 \mu \mathrm{M}$ of IBA +2.5 $\mu \mathrm{M}$ of $\mathrm{BA}), \mathrm{T} 3,(2.0 \mu \mathrm{M} I \mathrm{BA}+10.0 \mu \mathrm{M}$ of $\mathrm{BA})$, $\mathrm{T} 4,(2.0 \mu \mathrm{M} \quad \mathrm{IBA}+20.0 \mu \mathrm{M}$ of $\mathrm{BA}), \mathrm{T} 5$, (MS+10.0 $\mu \mathrm{M}$ of $\mathrm{BA}), \mathrm{T} 6,(0.5 \mu \mathrm{M}$ of $2,4-\mathrm{D}$ $+25.0 \mu \mathrm{M}$ of NAA), T7, $(2.5 \mu \mathrm{M}$ of $\mathrm{BA}+2.5 \mu \mathrm{M}$ of NAA), T8, (15.0 $\mu \mathrm{M}$ of $\mathrm{KIN})$, and T9, control (growth regulators-free). All cultures were incubated in growth room at $26^{\circ} \mathrm{C}$ with 16 light 18 dark daily for 6 weeks. Data were recorded as callus formation (\%) as well as visual observation.

Petiole explants obtained from in vivoplant grown were used as initial explants for callus induction. The explants were sterilized and cultured under aseptic conditions on MS medium supplemented with $3 \%$ sucrose with
$30 \mathrm{~g} / \mathrm{l}$ sucrose, $7 \mathrm{~g} / \mathrm{l}$ agar. and various concentrations of P1 (10 $\mu \mathrm{M}$ BA), P2 $(0.5 \mu \mathrm{M}$ 2,4-D +25 $\mu \mathrm{M} N A A), P 3(2.5, \mu \mathrm{M} N A A+25 \mu \mathrm{M}$

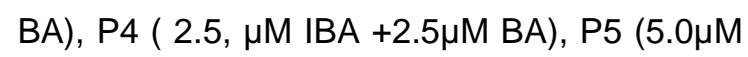

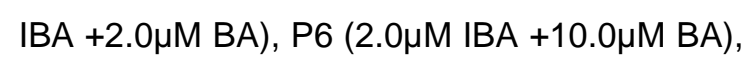

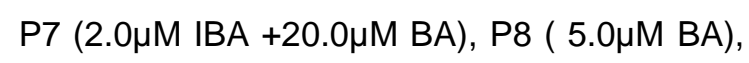
P9 $(2.0 \mu \mathrm{M}$ IBA $+5.0 \mu \mathrm{M} \mathrm{BA})$, and P10 (control without any growth regulators). All The $\mathrm{pH}$ value of all previous nutrient media was adjusted to $5.7 \pm 0.1$ prior to autoclaving at $121^{\circ} \mathrm{C}$ at $1.1 \mathrm{~kg} / \mathrm{cm}^{2}$ for 15 minutes. Cultures were incubated under $16 \mathrm{~h} / 8 \mathrm{~h}$ light/dark cycles at $26 \pm 2{ }^{\circ} \mathrm{C}$ from cool light fluorescent lamps. All cultures were incubated for 35 days and data were recorded as callus formation \%, Callus fresh \& dry weight, and visual observation as well.

Sterilized-Seed endosperm was excised (4 days-old) at the beginning of seed germination and cultured on MS basal solid medium in jars (ca. $350 \mathrm{ml}$ ) contained different growth regulators as $(2.5 \mu \mathrm{M}$ of $\mathrm{IBA}+7.5 \mu \mathrm{M}$ $\mathrm{BA}),(5.0 \mu \mathrm{M}$ of IBA+12.5 $\mu \mathrm{M} \mathrm{BA}),(7.5 \mu \mathrm{M}$ of IBA+20.0 $\mu \mathrm{M} \mathrm{BA}),(10.5 \mu \mathrm{M}$ of IBA+25.0 $\mu \mathrm{M}$ $\mathrm{BA})$, (Control with charcoal I+ ascorbic acid), and (Control without charcoal + ascorbic acid). All jars were incubated as mentioned prior for 24 days. Data were recorded as callus formation $\%$, and visual observation as well.

\section{Preparation of extracts}

\section{Crude extract preparation}

The powdered material from leaf, stem, root and seed coat) of Jatropha curcas L. and callus induced from cotyledonary leaf, hypocotyl, node and petiole explants. The dried samples were first chopped and then grinded with ordinary grinder to obtain dried fine powder. About $10 \mathrm{~g}$ of dried powder from each sample were extracted by absolute ethanol and methanol $70 \%$ for hypocotyl- 
derived callus as well. It was then concentrated to dryness under vacuum pressure by rotary evaporator (Buchi Rota vapor R-114). The dried samples were dissolved in dimethyl sulfoxide (DMSO) at various levels for studying antibacterial activity of bioactive compounds against some pathogenic positive and negative gram bacteria.

\section{Fractionation of crude extract}

The crude extract prepared from the dried hypocotyl callus of Jatropha curcas $L$. was divided into two portions; one portion was taken into glass vials to be tested as crude methanol extract for antimicrobial activity, while the second portion was taken into a glass beaker for fractionation with different solvents. The second portion was dissolved in water, poured into a separating funnel and then distilled petroleum ether was added. The separating funnel was shaken to separate the two phases as petroleum ether is immiscible with water. Compounds soluble in the upper petroleum ether were collected and the lower aqueous phase was extracted thrice with petroleum ether. All fractions of petroleum ether were combined and evaporated, leaving behind semisolid petroleum ether fraction. The semisolid petroleum ether fraction was dried via water bath at about $45^{\circ} \mathrm{C}$ and stored in the glass vials until used. Solvent extraction methodology was carried out for dichloromethane, ethyl acetate and butanol respectively. The lower aqueous phase at the end of the process was taken and dried via rotary evaporator and water bath. In this way six different extracts, that is, crude methanol extract, petroleum ether fraction, dichloromethane fraction, ethyl acetate fraction, butanol fraction and aqueous fraction were prepared and stored until used.

\section{Phytochemical analysis of plant extracts}

Various phytochemical tests were done to detect the presence of active chemical constituents like total of alkaloids according to (Sabri et al.,1973), flavonoids (Zhuang et al., 2001), glycosides (Dubois et al., 1956, lipid (Balbaa, 1986), terpenoids (Ebrahimzadeh and Niknam ,1998), and protein (Abouzaid, 1984) in callus extracts and in mother plant organs The biological activity assay of Jatropha curcas $L$.

\section{Preparation of media}

The required quantities of Luria-Bertani (LB) agar media (2.8 g $100 \mathrm{ml}-1)$ and nutrient broth (1.3 g $\left.100 \mathrm{ml}^{-1}\right)$ were prepared in distilled water and poured into conical flasks. Some of the nutrient broth (approximately $20 \mathrm{ml}$ test tube-1) was also poured into the test tubes. All the media flasks and test tubes were plugged with cotton wool and then sterilized in an autoclave at 1.5 pounds pressure and $121^{\circ} \mathrm{C}$ for $15 \mathrm{~min}$. After sterilization, nutrient agar media was poured aseptically into sterilized Petri plates in a laminar flow hood. Petri plates were placed in inverted position in an incubator at $37^{\circ} \mathrm{C}$ for $24 \mathrm{~h}$. After $24 \mathrm{~h}$, uncontaminated plates were used for culturing of bacteria. The nutrient broth in the flasks (approximately 20 ml flask-1) were used for shaking incubation of the microorganisms while nutrient broth in test tubes were used for standardization of microbial cultures.

\section{Microorganisms used}

The test microorganisms used in this study were Staphylococcus aureus (ATCC №.6538) Escherichia coli (ATCC № 10536), Bacillus cereus (EMCC № 1283 ${ }^{\text {TM }}$ ) and 
Bacillus subitlis (ATCC № 6633). All the microbial stock cultures were freshened by streaking using sterile inoculation loop on nutrient agar media plates in a laminar flow hood and incubated at $37^{\circ} \mathrm{C}$ for $24 \mathrm{~h}$. Each bacterial culture was further maintained at $37^{\circ} \mathrm{C}$ on nutrient agar slants at $2-8^{\circ} \mathrm{C}$ and nutrient broth after every 48 hours of transferring.

\section{Disc diffusion susceptibility method}

The antibacterial activity of the crude extracts was determined in accordance with the Disc Diffusion method (Jan Hudzicki ,2009). In this method, nutrient agar media plates were seeded with 18 to $24 \mathrm{~h}$ cultures of microbial inoculums. Whatman №. 1 filter paper discs (6 $\mathrm{mm}$ in diameter) were placed with the help of a sterile forceps on the media and then plant extracts in concentration of 40 $\mu \mathrm{l}$ disc-1. Antibiotics $(40 \mu \mathrm{l}$ disc-1) as positive control and dimethyl sulfoxide (DMSO) (40 $\mu \mathrm{l}$ disc-1) as negative control were also applied on the discs. Inoculated plates were then incubated at $37^{\circ} \mathrm{C}$ for 18 to $24 \mathrm{~h}$. The next day, zones of inhibition were recorded in millimeter around the discs in each plate. The control for bacteria was ciprofloxacin (30 $\mu \mathrm{g}, 6 \mu \mathrm{l}-1)$. Antibacterial activity determined by measuring the diameters of zone of growth inhibition $(\mathrm{mm})$. The experiments were conducted in triplicate. The data was expressed as means. The same procedure was followed for each microorganism to get the best possible results and clear any uncertainty regarding the results.

\section{Statistical analysis}

The experiments were set up in a completely randomized design. Data represented as mean were analyzed by analysis of variance (ANOVA) By SPSS program (version,26) and compared using Duncan t-test at $\alpha=0.01$ and 0.05 . LSD for significant differences were calculated, (Steel et al., (1997).

\section{RESULTS AND DISCUSSION}

In vitro germination of Jatropha curcas seeds:

Data in Fig. (1) clearly, show germination percentage of Jatropha curcas as affected by some famous nutrient media namely MS, B5 and WPM as well as wetted cotton and distilled water. Germination \% was $100 \%$ after 13 days for wetted cotton and after 24 days with WPM. B5 nutrient medium achieved $95 \%$ and MS recorded $88 \%$ while seeds soaking in distilled water recorded 86.67 $\%$ after 13 days. Data in Table (1) illustrate the effect of nutrient medium (B5, MS and WPM), as well as wetted cotton and distilled water on in vitro growth of Jatropha curcas L. estimated as shoot and root formation as well as shoot fresh \& dry weight. With respect to root length of the germinated seedlings, the germinated seeds in MS media recorded highest root length and root number $(0.69 \mathrm{~cm}$ and 4.63$)$ were recorded with MS medium. WPM was effective in increasing the total length of seedlings. The maximum dry weight $(0.24 \mathrm{gm})$ resulted from $0.99 \mathrm{gm}$ fresh weight was recorded with B5 medium. Results under discussion are in line with Warakagoda and Subasinghe (2009) who collected Jatropha curcas seeds (immature, mature and fully mature) and surface sterilized seeds were inoculated on Murashige and Skoog (MS), 
McCown's Woody Plant (WPM) and B5 medium with and without incorporating activated charcoal at $1 \mathrm{~g} / \mathrm{l}$. Mature seeds in B5 medium showed early seed germination and best seedling growth than immature and fully mature seeds in B5, MS and WPM media. Further studies are required to optimize the findings presented here as tissue culture remains an important propagation tool for
Jatropha curcas L. Regarding shoot length WPM was the best nutrient medium with nonsignificant difference between WPM and MS, as well as among different treatment used except B5 nutrient medium where this difference was not significant $(P \leq 0.01)$. It may be to the components of WPM and B5 medium.

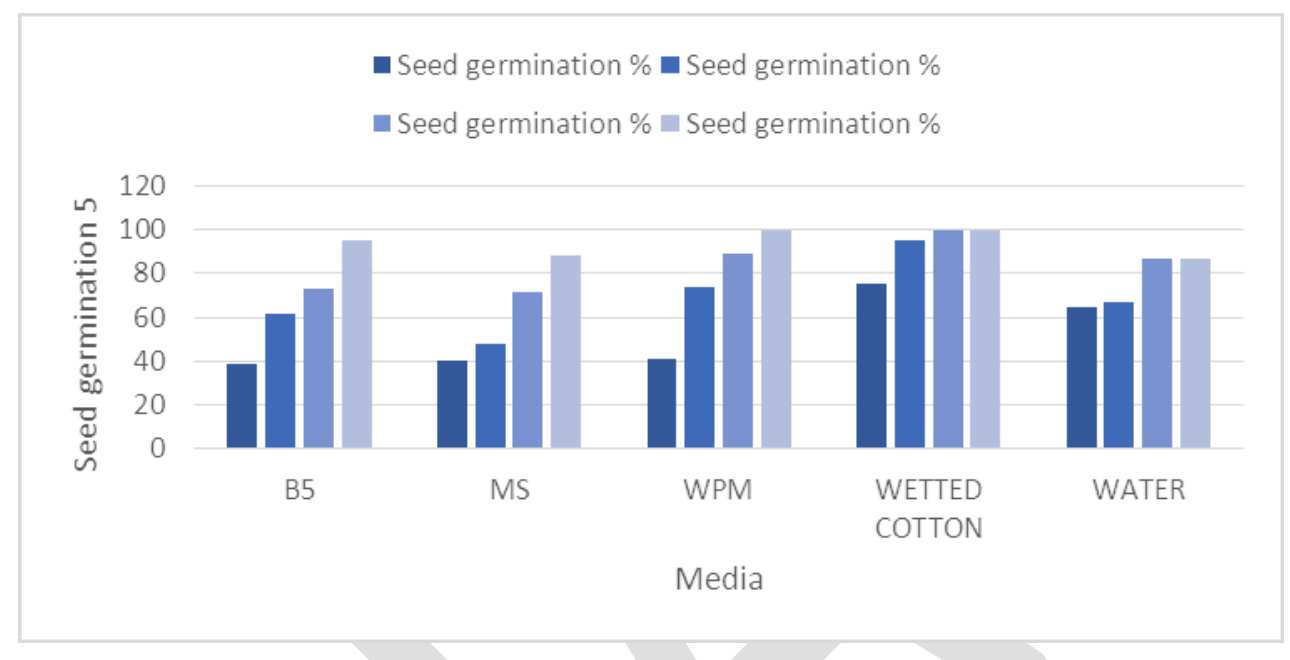

Fig. (1): Seed germination percentage of Jatropha curcas L. (after 4, 10, 13 and 24 days from culturing) on B5, MS, WPM, Wetted Cotton and Distilled Water.

Regarding root length, Although, WPM nutrient medium recorded the longest root 1.36 $\mathrm{cm}$, no significant differences among different nutrient media B5 and WPM and wetted cotton $(P \leq 0.01)$. Shoots grown on distilled water did not form roots. It seems that nutrient medium has a high concentration of salts as WPM recorded the tallest roots comparing to other nutrient media and wetted cotton.

It may be due to MS nutrient medium which the seeds germinate in the same medium and transfer to it and the seeds germinate in wetted cotton and transfer to MS nutrient medium. Then the main problem due to MS nutrient medium either in the first in vitro seed germination medium (Table,1) or in vitro cultivation medium. Seedling dry weight was affected by nutrient medium used. B5 recorded $240 \mathrm{mg} /$ plantlet, while MS and WPM recorded $80 \mathrm{mg} /$ plantlet. Shoots grown on wetted cotton and distilled water did not achieve good growth and subsequently suitable dry weight which recorded $30 \mathrm{mg} / \mathrm{shoots}$. These results are in line with Sillma et al., (2014), Pantipa et al., (2015) and Cecilia et al., (2016). Who can regenerate Jatropha curcas L. "in vitro" as an important biofuel plant. 
Table (1): Effect of different media (B5, MS, and WPM), wetted cotton, water on seedling growth of Jatropha curcas.

\begin{tabular}{|c|c|c|c|c|c|c|}
\hline Media & $\begin{array}{c}\text { No of } \\
\text { leaves/expl. }\end{array}$ & $\begin{array}{c}\text { Shoot } \\
\text { length/expl. } \\
\text { (cm) }\end{array}$ & $\begin{array}{c}\text { Root } \\
\text { length } \\
\text { lexpl. }\end{array}$ & $\begin{array}{c}\text { Root } \\
\text { No./expl } \\
\text { (cm) }\end{array}$ & $\begin{array}{c}\text { Fresh } \\
\text { wt. } \\
\text { (g) }\end{array}$ & $\begin{array}{c}\text { Dry } \\
\text { wt. (g) }\end{array}$ \\
\hline B5 & 3.04 & 2.49 & 0.92 & 4.0 & 0.99 & 0.24 \\
\hline MS & 2.58 & 2.25 & 0.69 & 4.63 & 0.45 & 0.08 \\
\hline WPM & 2.50 & 2.83 & 1.36 & 4.40 & 0.53 & 0.08 \\
\hline W. COTTON & 2.0 & 1.61 & 0.94 & 3.75 & 0.20 & 0.03 \\
\hline WATER & 2.0 & 0.96 & 0 & 0.0 & 0.71 & 0.04 \\
\hline LSD 1\% & 0.597 & 0.962 & 0.640 & 1.116 & 0.261 & 0.222 \\
\hline
\end{tabular}

\section{Callus initiation}

\section{Effect of growth regulators}

cotyledonary leaves Explants from 15-

17 days-old seedlings of $\mathrm{J}$. curcas were transferred to B5 medium as callus induction medium and cultured in climate chamber at $26^{\circ} \mathrm{C}$ in the dark for 35 days. The results show that different plant hormones could induce callus formation, as well as the medium supplied with $2.5 \mu \mathrm{M} \mathrm{TTZ}$ and $5.0 \mu \mathrm{M}$ as a new substance used in plant tissue culture. BA was the most significant among the other mediums; the rate of callus induction reached $100 \%$ (Figure,3).

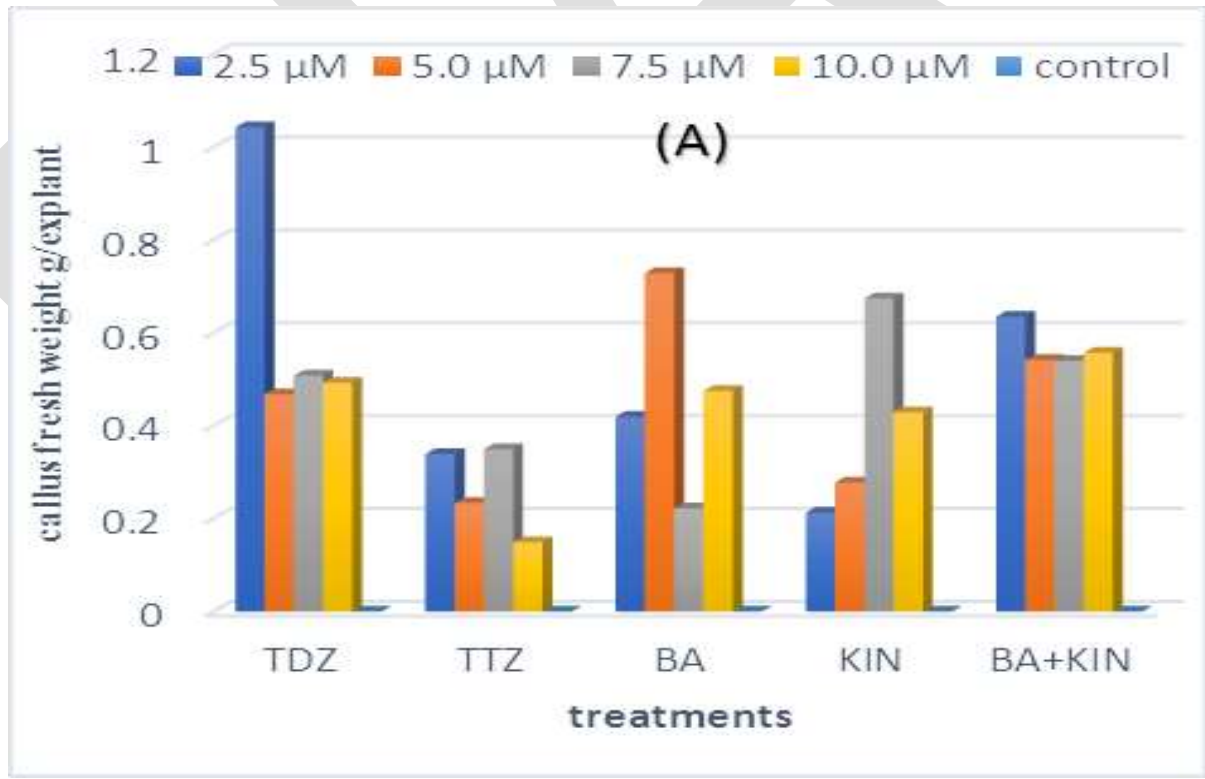




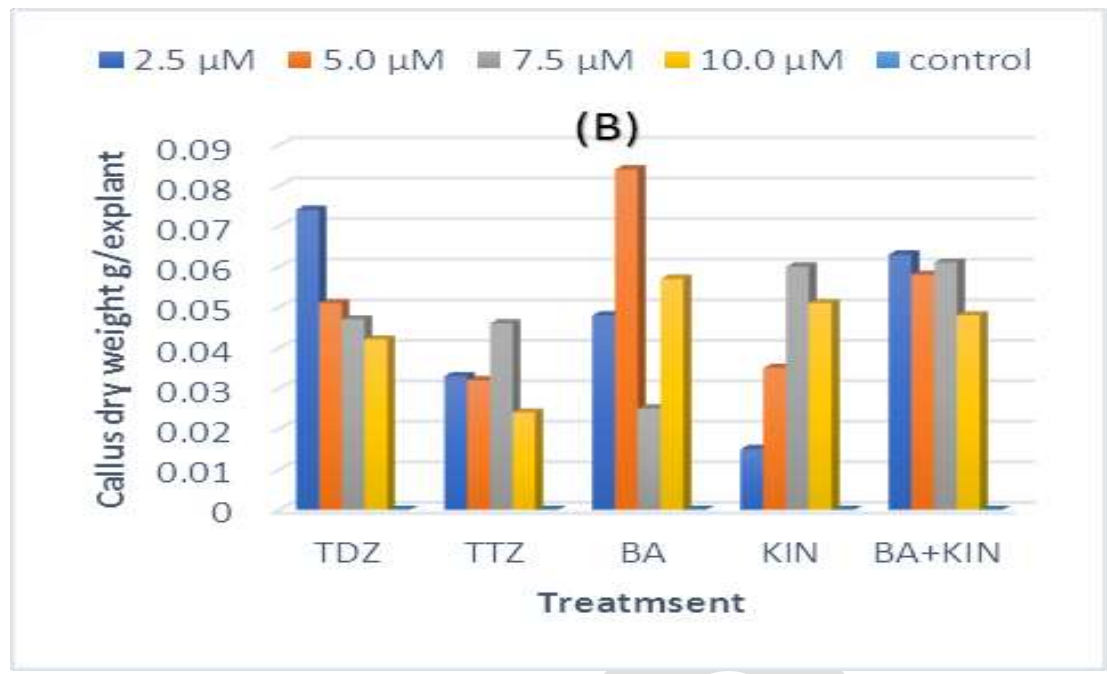

Fig. (3): Effect of Plant growth regulators on(A) callus fresh weight and (B) dry (g/explant) derived from cotyledonary leaves of Jatropha curcas.

Furthermore, appropriate combination of concentration of plant hormone for callus induction, sterilized explants were transferred to the medium with the combination of different concentrations of TDZ, TTZ, BA, KIN and $\mathrm{BA}+\mathrm{KIN}$ respectively. As shown in Figure 3 , different plant hormones could induce the formation of callus and stimulate callus growth, especially in TDZ in rate of $2.5 \mu \mathrm{M}$ where achieved the highest amount of fresh weight (1.043 g/explant), followed by $5.0 \mu \mathrm{M} \mathrm{BA}$, that recorded $0.729 \mathrm{~g} / \mathrm{explant}$ which were the most significant as compared with the other treatments. Statistical analysis was appeared significant differences $(P \leq 0.01)$ between the levels used, also from the results, it is evident that, TTC may be a promising substance will be possible used in plant tissue culture, where The fresh weight of callus that was grown on medium contained TTC in different levels achieved a positive response in all levels. The highest amount of callus fresh weight $(0.350$ g/explant) was recorded with $7.5 \mu \mathrm{M}$ followed by $2.5 \mu \mathrm{M}(0.339 \mathrm{~g} / \mathrm{explant})$ but another two levels were 0.234 and $0.149 \mathrm{~g} / \mathrm{explant}$, with 5.0 $\mu \mathrm{M}$ and $10.0 \mu \mathrm{M}$ respectively. Concerning callus dry weight, (Fig.3) there are a little change in order where, BA recorded the highest dry weight of callus amount $(0.084$ g/explant), followed by TDZ (0.074 g/explant).With regard to TTC, the results were emphasized that, the dry matter of callus grown on MS medium containing different concentrations of TTC achieved remarkable improvement and recorded higher levels of dry weight as comparing to other hormones used, particularly at the level of $7.5 \mu \mathrm{M}$. This means, more attention should be taken for using TTC in widely in the field of tissue culture as a new substance. These data implied that different plant hormones tested could induce the formation of callus in cotyledon of $J$. curcas seedlings, and the combination of BA and Kin in various concentrations was an appropriate medium for inducing the formation of callus and promoting its growth.

\section{Effect of growth regulators and explant types on callus initiation}

Data in figure (4) showed that, there are significance difference between the three types of explants (Hypocotyl, Node and Leaf) in formation of callus on different types of 
media through different incubation periods. Callus formed from the explants was soft and friable, white to light green in colour. Callus produced from hypocotyl explants grew faster during 7 to 30 days of culture,

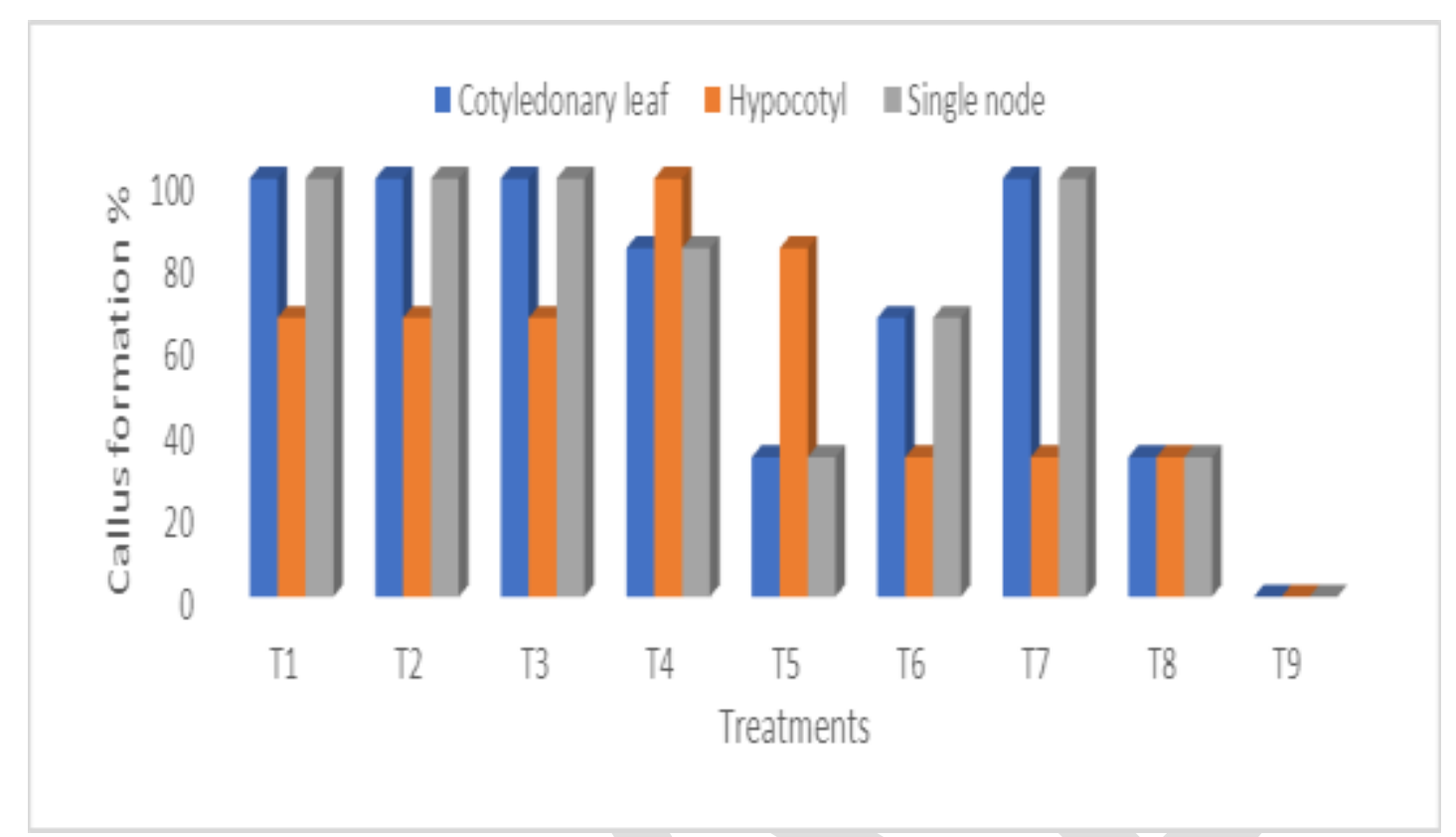

Fig. (4): Effect of growth regulators on callus formation \%, derived from different explant types and grown on MS basal solid medium

Where $\mathrm{T} 1=(0.5 \mu \mathrm{M}$ of $2,4-\mathrm{D}+2.5 \mu \mathrm{M}$ of $\mathrm{KIN}+15.0 \mu \mathrm{M}$ of $\mathrm{NAA}), \mathbf{T} 2=(2.0 \mu \mathrm{M}$ of IBA $+2.5 \mu \mathrm{M}$ of $\mathrm{BA}), \mathrm{T} 3=(2.0 \mu \mathrm{M}$ IBA $+10.0 \mu \mathrm{M}$ of $\mathrm{BA}), \mathbf{T 4}=(2.0 \mu \mathrm{M} \mathrm{IBA}+20.0 \mu \mathrm{M}$ of $\mathrm{BA}), \mathbf{T} 5=$ $(\mathrm{MS}+10.0 \mu \mathrm{M}$ of $\mathrm{BA}), \quad \mathrm{T} 6=(0.5 \mu \mathrm{M}$ of $2,4-\mathrm{D}$ $+25.0 \mu \mathrm{M}$ of NAA $), \mathrm{T} 7=(2.5 \mu \mathrm{M}$ of $\mathrm{BA}+2.5 \mu \mathrm{M}$ of NAA), T8= $(15.0 \mu \mathrm{M}$ of $\mathrm{KIN})$, and $\mathbf{T 9}=$ control (growth regulators-free) then stabilized at a low growth rate. Hypocotyl gave the highest callus formation percentage (100\%) after 1 week on MS medium containing $0.5 \mu \mathrm{M}$ 2,4-D+2.5 $\mu \mathrm{M} \mathrm{KIN}+15.0 \mu \mathrm{M}$ NAA, followed by cotyledonary leaf $(16.67 \%)$ on MS medium has $0.5 \mu \mathrm{M} 2,4-\mathrm{D}+2.5 \mu \mathrm{M} \mathrm{KIN}+15.0 \mu \mathrm{M}$ NAA and $2.0 \mu \mathrm{M}$ IBA+2.5 $\mu \mathrm{M}$ BA.5 $\mu \mathrm{M}$ 2,4-D+25.0 $\mu \mathrm{M} N A A$ as well. while the nodes failed to give any callus formation percentage. Maximum response was achieved at the third week for all explants used. At the end of incubation, most of explants were formed one hundred percent $(100 \%)$ of callus, except of cotyledonary leaf on medium supplemented with $\mathrm{MS}+2.0 \mu \mathrm{M}$ IBA+2.5 $\mu \mathrm{M}$ BA and MS+2.0 $\mu \mathrm{M}$ IBA+10 $\mu \mathrm{M}$ $\mathrm{BA}$ (66.67\% for each), as well as, MS+2.0 $\mu \mathrm{M}$ IBA+20.0 $\mu \mathrm{M}$ BA and MS+15 $\mu \mathrm{M}$ Kin came at the last $(33.33 \%)$. There is no significance difference between the fourth and third weeks of incubation but there is significance difference $(P \leq 0.01)$ between the third and both second and first weeks of incubation, so the subculture after the third week was the best time. 


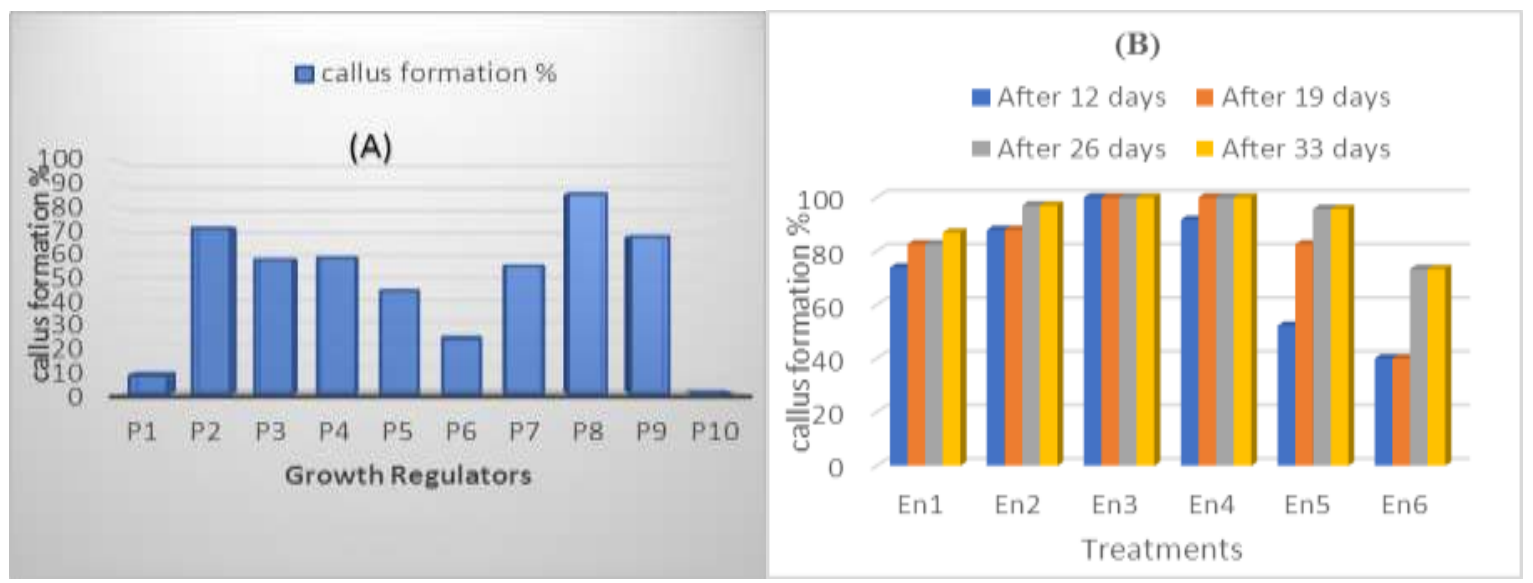

Fig. (5): Effect of growth regulators on callus formation \%,(A) derived from in vivo-petiole explant, grown on MS basal solid medium, Where: P1 (10 $\mu \mathrm{M} B A), \mathbf{P} 2(0.5 \mu \mathrm{M} 2,4-\mathrm{D}+25 \mu \mathrm{M} N A A), \mathbf{P 3}(2.5$,

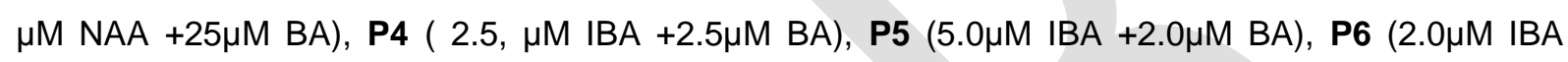

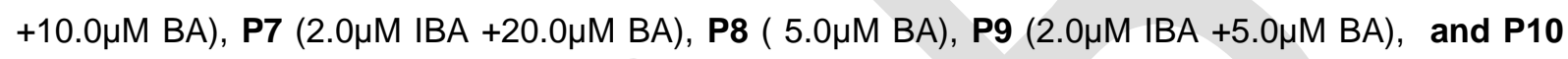
(control without any growth regulators), (B) from endosperm of Jatropha curcas at different interval times on different media composition. where, $1(2.5 \mu \mathrm{M}$ of IBA+7.5 $\mu \mathrm{M} \mathrm{BA}), 2(5.0 \mu \mathrm{M}$ of IBA+12.5 $\mu \mathrm{M}$ BA), $3(7.5 \mu \mathrm{M}$ of IBA+20.0 $\mu \mathrm{M} \mathrm{BA}), 4(10.5 \mu \mathrm{M}$ of IBA+25.0 $\mu \mathrm{M}$ BA), 5 (Control with charcoal + ascorbic acid), and 6 (Control without charcoal + ascorbic acid).

Data in Fig. (5-B) showed that, the highest percentage (100\%) of callus induction from endosperm explants was given by MS solid medium with $7.5 \mu \mathrm{M}$ IBA plus $20.0 \mu \mathrm{M}$ BA after 12 days of culturing whereas it was 100 $\%$ in MS contained $10.5 \mu \mathrm{M}$ IBA and $25.0 \mu \mathrm{M}$ BA after 19 days of culturing. Endosperm explant and $7.5 \mu \mathrm{M}$ IBA+20.0 $\mu \mathrm{M}$ BA to be most effective in inducing of callus on a large scale in short period of time. Callus formed from the endosperm was soft and friable, white to off yellow in colour (fig.,6). Callus produced from endosperm explants grew faster during 10 to 15 days of culture then stabilized at a low growth rate. The lowest percentage $(40.0 \%)$ of callus induction from endosperm explants was given by MS Control media without charcoal and ascorbic acid after 19 days of culturing, From the results, it could be concluded that, jatropha plant has wide range from growth regulators (auxins and cytokinins) and concentrations to take different response to form callus. This concept emphasize by Pei Hou, et al., (2006), they were taken The mature endosperms of $\mathrm{J}$. curcas as explants for callus induction, and $0.4 \mathrm{mg} / \mathrm{L}$ of cytokinin (BA, Kin and TDZ) and $2.0 \mathrm{mg} / \mathrm{L}$ of auxin (IAA, IBA, NAA and 2,4-D) were used to test callus induction efficiencies. The result showed that the efficiencies of BA and Kin were not quite different. Also, Makawat, et al., (2012) cultured Endosperm explants from Jatropha curcas L. on MS media supplemented with various concentrations of auxins (IBA, 2,4-D and NAA,) The results showed that, type of auxin and its concentration are critical factors for callus induction, whereas no callus was observed in the control medium and medium supplemented with $5 \mu \mathrm{M} 2,4-\mathrm{D}, \mathrm{NAA}$ and IBA. 


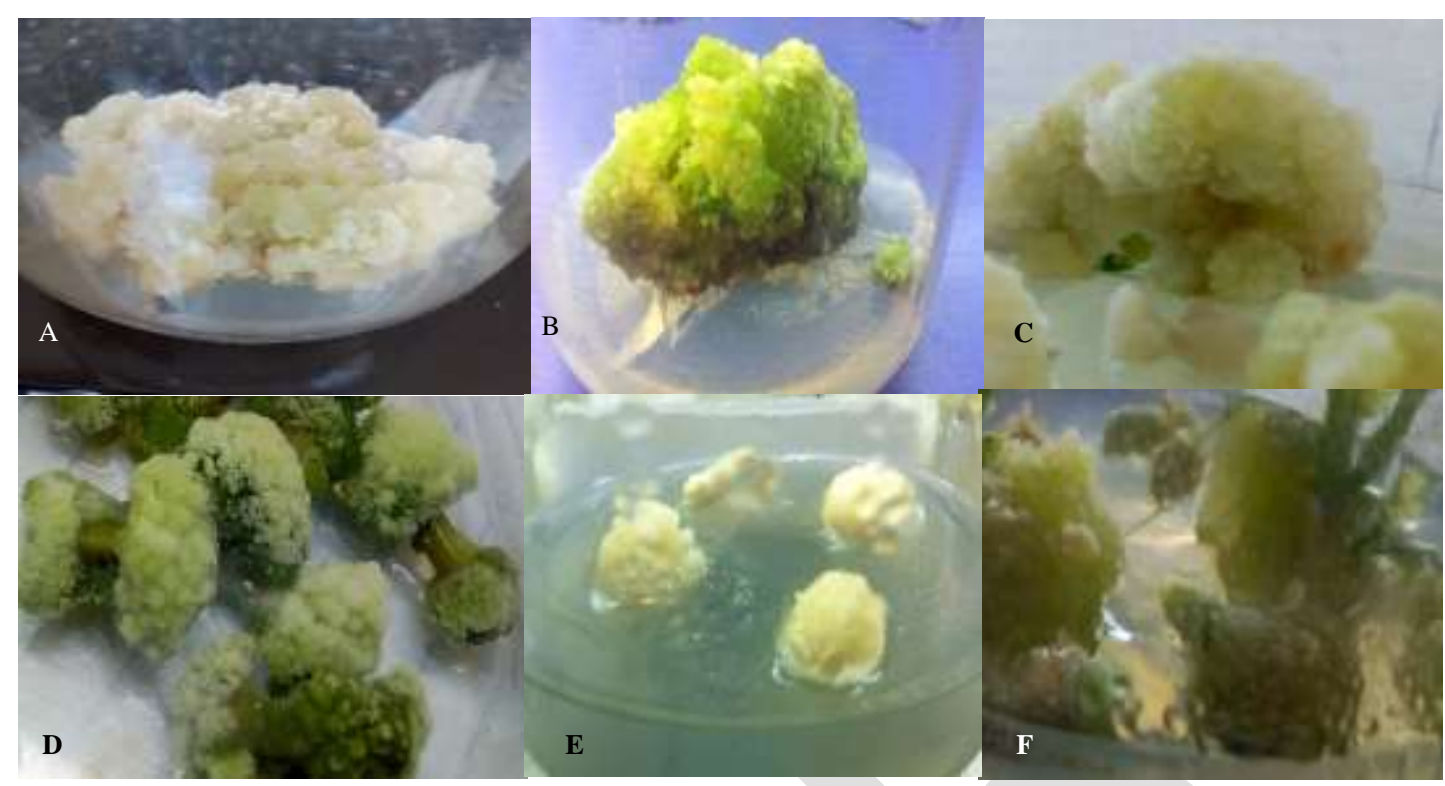

Fig.(6): Callus initiation of Jatropha curcas L. from different Explants (A) callus derived from leaf explants on MS medium, (B) callus from hypocotyl on MS+(0.5 $\mu \mathrm{M}$ of 2,4-D+2.5 $\mu \mathrm{M}$ of $\mathrm{KIN}+15.0 \mu \mathrm{M}$ of NAA), (C) callus from hypocotyl on MS+ $0.5 \mu \mathrm{M}$ of 2,4-D+25.0 $\mu \mathrm{M}$ of NAA, (D) callus from petiole on $M S=2.0 \mu \mathrm{M} I B A+20 \mu \mathrm{M} B A,(E)$ callus from endosperm on $M S+7.5 \mu \mathrm{M} I B A+20.0 \mu \mathrm{M} B A$ and $(F)$ callus from nodal explants

\section{Phytochemical screening of cultivated and in vitro samples}

Qualification phytochemical screening of the cultivated and in vitro samples as root of plant, stem of plant, plant leaf, seed, Petiole callus, and Leaf callus was carried out, positive results was achieved for, alkaloids, glycosides/carbohydrates, flavonoids, lipid, terpenoid, and proteins, as previously detected by (Soliman, 2009).

\section{Antibacterial Activity}

Antimicrobial activity of extracts from root of Jatropha curcas.

Data in Table (2) show that, root extract found to be highly active against all the 4 bacteria tested. The results of triplicate analysis demonstrate that, the root extract alone showed reasonable activity against the tested organisms even at lower concentrations of $0.938 \mathrm{mg} / \mathrm{ml}$. The inhibition zone diameters were in the range of 6.0 to $23 \mathrm{~mm}$ for $B$. cereus, in the range of 12 to $15.66 \mathrm{~mm}$ for $S$. aureus, and 7 to $11.0 \mathrm{~mm}$ for E.coli at concentrations between 15 to $60 \mathrm{mg} / \mathrm{ml}$. for, $B$. subtilis was 11 to $20.67 \mathrm{~mm}$ between 7.5 to 60 $\mathrm{mg} / \mathrm{ml}$ using a dual serial dilution. From the results, it's clear that, higher resistance of gram-positive bacteria was achieved with $S$. aureus $(15.66 \mathrm{~mm})$ and $B$. subtilis $(20.67 \mathrm{~mm})$ at high rate of extract $(60 \mathrm{mg} / \mathrm{ml})$, while gramnegative bacteria, E. coli recorded $(11 \mathrm{~mm})$ at the same concentration., This results close to finding Okoye COB, (2013), he studied, The bacteriostatic activities of the graded concentration of the extract of Jatropha curcas 
root and he found that, the sensitivity pattern of the tested organisms; S. aureus and E.coli demonstrates that both organisms were susceptible. The inhibition zone diameters for
$S$. aureus were in the range of $3.0 \mathrm{~mm}$ to $13.06 \mathrm{~mm}$ and $3.03 \mathrm{~mm}$ to $10.0 \mathrm{~mm}$ for E. coli at concentrations between 1.5625 to 200 $\mathrm{mg} / \mathrm{ml}$ using a twofold serial dilution.

Table (2): Inhibition Zone Diameters $(\mathrm{mm})$ at various concentration $(\mathrm{mg} / \mathrm{ml})$ of the ethanol extract of $J$. curcas root using a dual serial dilution.

\begin{tabular}{|c|c|c|c|c|c|c|c|c|}
\hline \multirow{2}{*}{$\begin{array}{c}\text { Test } \\
\text { Organisms }\end{array}$} & \multicolumn{8}{|c|}{ Inhibition zone $(\phi \mathrm{mm})$} \\
\cline { 2 - 10 } & 60 & 30 & 15 & 7.5 & 3.75 & 1.875. & 0.938 & 0.469 \\
\cline { 2 - 10 } & 11 & 9 & 7 & - & - & - & - & - \\
\hline E. coli & 15.66 & 14.33 & 12 & - & - & - & - & - \\
\hline S. aureus & 23 & 22 & 21 & 18 & 15 & 10.33 & 6.0 & - \\
\hline B. cereus & 20.67 & 19 & 15 & 11 & - & - & - & - \\
\hline B. subtilis & & & & & & & & - \\
\hline
\end{tabular}

Table (3): Inhibition Zone Diameters $(\mathrm{mm})$ at various concentration $(\mathrm{mg} / \mathrm{ml})$ of the ethanol extract of callus derived from leaf of $J$. curcas using a dual serial dilution

\begin{tabular}{|l|c|c|c|c|c|c|}
\hline \multirow{2}{*}{ Microorganisms } & \multicolumn{7}{|c|}{ Inhibition zone $(\phi \mathrm{mm})$} \\
\cline { 2 - 7 } & 100 & 50 & 25 & 12.5 & 6.25 & 3.125 \\
\cline { 2 - 7 } & & & & & & \\
E. coli & 10 & 9.3 & 7.0 & - & - & - \\
\hline S.aureus & 12 & 10 & 9 & 6 & - & - \\
\hline B.cereus & 19 & 14.67 & 13.33 & 11.67 & 10 & - \\
\hline B.subtilis & 15 & 11 & 8.5 & - & - & - \\
& & & & & & \\
\hline
\end{tabular}

Data in table (3) show that, callus derived from leaf of Jatropha curcas found to be highly active against all the 4 bacteria tested at high concentration. Ethanol extract of leaf callus showed higher sensitive to gram positive bacteria, $B$. cereus $(19.0 \mathrm{~mm})$ and $B$. subtilis $(15.0 \mathrm{~mm})$ at high rate of extract (100 $\mathrm{mg} / \mathrm{ml}$ ) while gram negative bacteria, E. coli recorded high resistance $(10 \mathrm{~mm})$ with the same concentration. On the other hand, $B$. cereus is found to be more sensitivity, where appeared positive effect with the low concentration. The results demonstrate that, the leaf callus extract showed reasonable activity against the tested organisms even at lower concentrations of $6.25 \mathrm{mg} / \mathrm{ml}$. The inhibition zone diameters were in the range of 10 to $19 \mathrm{~mm}$ for $B$. cereus and $E$. coli appeared high resistance of leaf callus extract for all bacteria tested. 


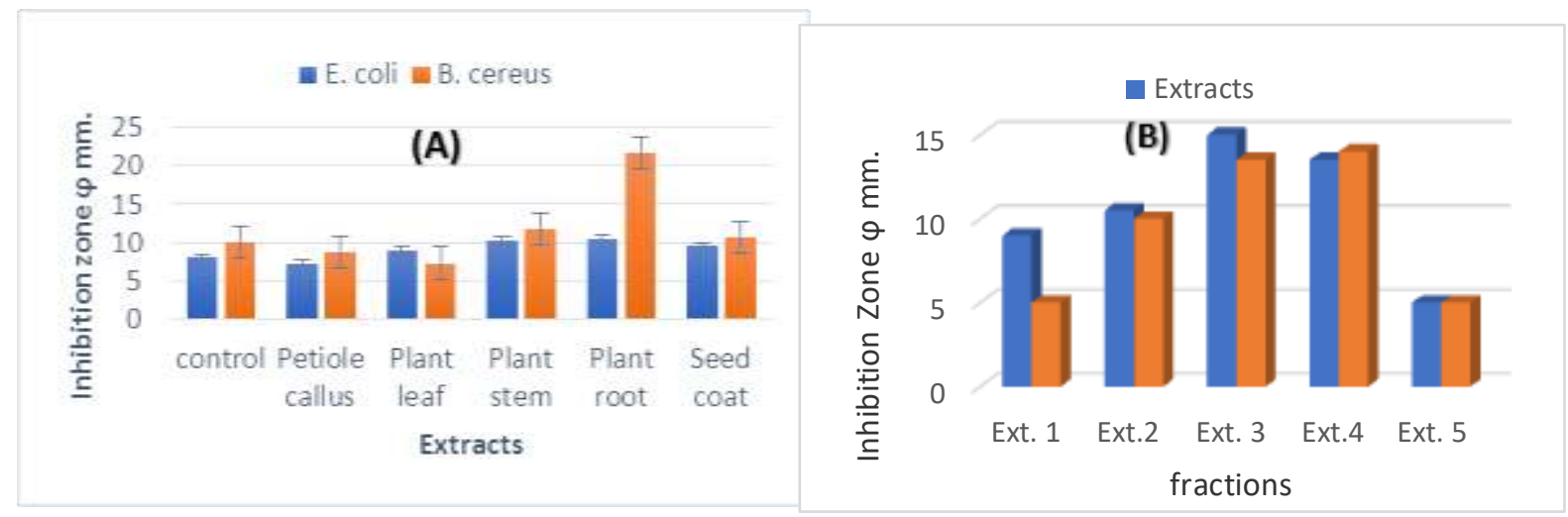

Fig. (7): Antibacterial activity of (A) different ethanolic extracts of petiole-derived callus as well as, leaf, stem, root, and seed coat of Jatropha curcas L. on E. coli. and B. cereus, (B) Different fractionations of crude methanolic extract of hypocotyl-derived callus on antibacterial activity of $E$. coli.

Where: Ext.1=methanolic extract, Ext.2=dichloromethane fraction, Ext3 = butanol fraction, and Ext. 4= ethyl acetate fraction Ext. $5=$ aqueous extract

Data in Fig., (7-A) appeared that, ethanolic crude extract from all plant parts tested had higher bioactivity against $E$. coli and B. cereus. Extract from the plant root was found to show strong antimicrobial activity for B. cereus $(21.7 \mathrm{~mm})$, followed stem extract $(11 \mathrm{~mm})$, while the both extracts had equal effect against $E$. coli and B. cereus. and ethanolic extracts from leaf of $J$. curcas and petiole-derived callus were the lowest effective among all plant extracts tested against $E$. coli and $B$. cereus and ineffective as comparison to control. It was observed that root was the most effective among the four plant extracts tested. It showed a zone of inhibition (ZOI) against all gram positive and gram-negative bacteria tested.

Evaluation of the antimicrobial activity of four different fractions resulted from crude methanolic extract of hypocotyl-derived callus was determined initially by the disc diffusion method against E. coli, (Fig., 7-B). This micro-organism was frequently encountered in infectious diseases. The study showed that, all fractionations used in the study exhibited a varying degree of antimicrobial activity against the microorganism tested. It was observed that butanol fraction (Ext.3) was the most effective among the extracts tested. It showed a zone of inhibition against E. coli. (gram negative bacteria tested) whereas there was no activity of water fractions (Ext5) against negative bacteria. Successive isolation of active compounds from plants depends upon the type of solvent used in extraction procedure.

Our results showed that, the activity is mainly concentrated in the butanol and ethyl acetate fraction. The potential antimicrobial compounds were in the high polarity fractions. Such results agreement with other data reported that, antibacterial activity of the fractions and the crude extract exhibited varying degree of antibacterial effect against the test organism (E. coli) in a concentrationdependent manner. The solvent type used for the extraction also played a major role. 
Mahasneh and EL-Oqlah (1999) concluded that butanol extracts have superior antimicrobial activity compared with other ones, Also in this concept, Shehla Khan, et al., (2018), they found that, butanol extracted fraction at $3 \mathrm{mg} / \mathrm{disc}$ respectively, has maximum activity of $79 \%$ against $E$. coli. Also, the decrease in activity of aqueous extract can be ascribed to the enzyme polyphenol oxidase, which degrades polyphenols in water extracts, whereas in methanol and ethanol they are inactive (Lapornik et al., 2005). Data in Fig., (8) showed that, ethanolic extracts from petiole, leaf and hypocotyl callus was found to have antimicrobial activity against E. coli. Hypocotyl callus found to be superior extract for antimicrobial activity against $E$. coli gram negative bacteria, followed by petiole callus extract as comparing to control. This result agreed with Bekhit et al., (2007), they found that, ethanolic extracts from Ginkgo leaves, and in vitro leaf-callus has inhibited effect of the growth of $E$. coli .

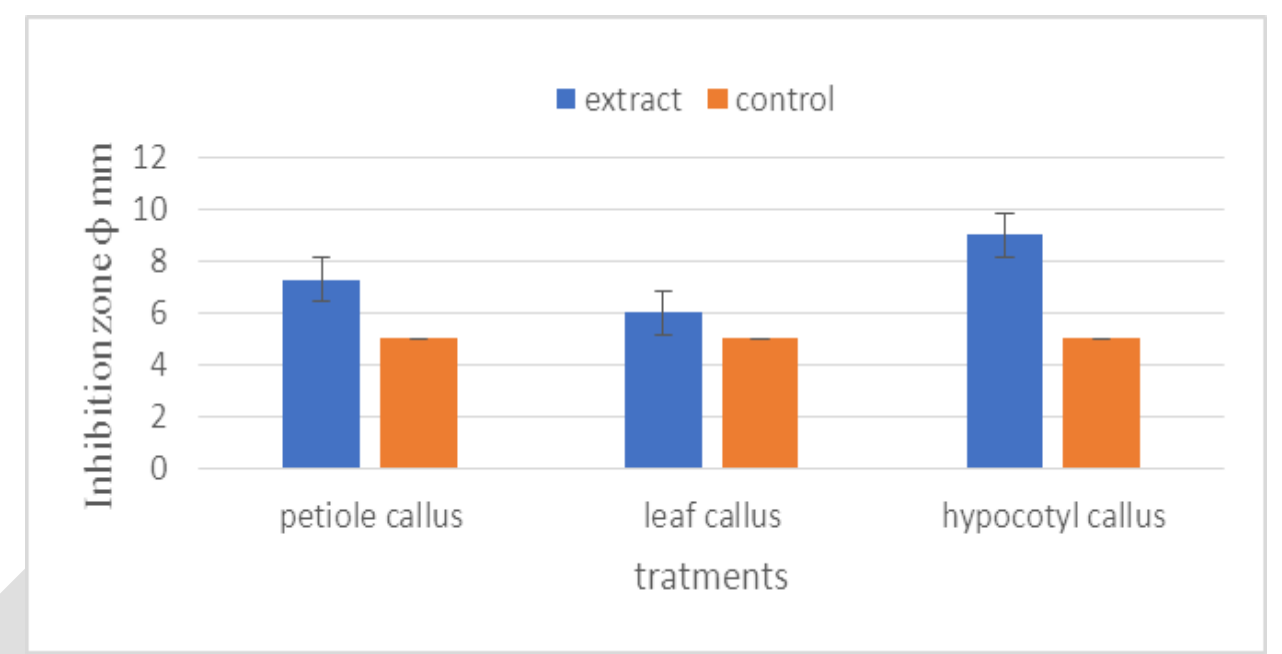

Fig. (8): Antimicrobial activity of extracts from callus derived from petiole, leaf and hypocotyl of Jatropha curcas explants on E. coli.

Generally, from antimicrobial activity study. It could be concluded that, the results are found different degrees of antimicrobial activity against all bacteria tested, as $E$. coli (gram negative bacteria) and $S$. aureus, B.cereus, B.subtilis (gram positive bacteria). The results indicate that there are differences that may be due to many factors that have been pointed out through many studies, the factors affecting the choice of solvent are quantity of phytochemicals to be extracted, rate of extraction, diversity of different compounds extracted, diversity of inhibitory compounds extracted, ease of subsequent handling of the extracts, toxicity of the solvent in the bioassay process and potential health hazard of the extractants (Eloff, 1998). Plant extracts using organic solvents have been found to give more consistent antimicrobial activity compared to water extract. The higher activity of the ethanolic extracts as compared to the aqueous extract can be attributed to the presence of higher amounts of polyphenols as compared to aqueous extracts. Ethanol ability to extract more components. This may be the reason for the presence of large number of phytochemicals in ethanol extract (Arekemase et al., 2011). The higher concentrations of 
more bioactive flavonoid compounds were detected with ethanol $70 \%$ due to its higher polarity than pure ethanol (Bimakr et al., 201I). Additionally, ethanol possibly penetrates the cellular membrane easily to extract the intracellular ingredients. Also, phytochemicals alkaloids, flavonoids, terpenoids, tannins, fats and oils and protein present in extracts of $J$. curcas show antimicrobial activities.

\section{Conflicts of Interest}

The authors declare that they have no conflicts of interest.

\section{CONCLUSION}

Nowadays focus is being placed on $\mathrm{J}$. curcas plant uses and its effects in various fields. So, this study showed the importance of obtaining strong seedlings with good specifications, free of diseases and with a high percentage of seed germination (100\%) during a short period of time. Also, callus formation is central to many investigative and applied tissue culture procedures. Callus can be multiplied and later used to clone numerous whole plants. Since extensive callus formation can be induced by elevated hormone levels, tissue culture media designed to produce callus contain pharmacological additions of cytokinins and auxins. The balance between auxin and cytokinin is the limited factor for callus induction and growth. MS nutrient medium supplemented with 2,4 -D or NAA or both helped to form callus at high percentage. Although there are no previous research studies on triphenyl tetrazolium chloride (TTC), it has produced promising results, especially in the production of callus, but more attention is needed to achieve the desired goal for use in tissue culture. Discover of a new substance may open up promising prospects in the field of biotechnology. the efficacy of some selected plant extracts was confirmed as natural antimicrobials and suggested the possibility of employing them in drugs for the treatment of infectious diseases caused by the test organisms. Ethanolic extract from all plant parts tested had higher bioactivity compared to methanol and aqueous fraction extracts. Successful determination of biologically active compounds from plant material is largely dependent on the type of solvent used in the extraction procedure and quantity of phytochemicals to be extracted.

\section{ACHNOWLEDGEMENTS}

The authors wish to thank the Department of Microbial Biotechnology, Genetic Engineering and Biotechnology
Research Institute, University of Sadat City, for providing facilities and technical support. 


\section{REFERENCES}

Abouzaid M.A. (1984): Biochemical studies on fodder yeasts. Ph.D. Thesis, Cairo Univ. Egypt.

Adebowale K.O, and Adedire C.O., (2006).

Chemical composition and insecticidal properties of the underutilized Jatropha curcas seed oil. African Journal of Biotechnology 5: (10), 901-906, http://www.academicjournals.org/ AJB

Alviano D.S, and Alviano CS., (2009). Plant extracts: search for new alternatives to treat microbial diseases. Curr Pharm Biotechnol.10 (1):106-121.

Arekemase, M. O., Kayode, R. M. O., and Ajiboye, A. E., (2011). Antimicrobial activity and phytochemical analysis of Jatropha curcas plant against some selected microorganisms. Int. J. Biol. 3: 52.

Balbaa, S.I., (1986): Chemistry of crude drugs. Laboratory Manual, Faculty of Pharm., Cairo Univ., pp 195.

Bimakr M., Rahman, R.A., Taip, F.S., Ganjloo, A., Saleh, L.M., Selamat, J., Hamid, A., and Zaidul, I., (2011). Comparison of different extraction methods for extraction of major bioactive flavonoid compounds from spearmint (Mentha spicata L.) leaves. Food and Bioproducts Processing. 89, 67-72.

Cecilia M.M., Aggrey N. and Justus O., (2016). Efficient somatic embryogenesis of Jatropha curcas L. from petiole and leaf discs. Int. J. Biotechnol. Mol. Biol. Res, 7(3):29-35.

Dubois, M. Gilles, K.A., Hamilton, J.K., rebels, R.A., and Smith, F., (1956). Colorimetric method for determination of sugars and related substances.

Anal.Cheri.,28: 87.

Ebrahimzadeh X.P., Lu Y.Y and Nikname Yang G.S., (1998). A revised spectrophotometrically method for determination of triterpenoid saponin. Indian Drugs. 35:379381.

Eggleston K, Zhang R, and Zeckhauser RJ., (2010). The global challenge of antimicrobial resistance: insights from economic analysis. Int $\mathrm{J}$ Environ Res Public Health. 7(8):3141-3149. doi: 10.3390/ijerph7083141.

Eloff, J.N., (1998). Which extractant should be used for the screening and isolationof antimicrobial components from plants? Journal of Ethnopharmacology 60,1 - 8.

Gandhi V M, Cherian K M, and Mulky M. D., (1995). Toxicological studies on Ratangyat oil. Food chem. Toxical. 33 : ( 1 ) 39-42.

Gamborg OL, Miller RA, and Ojima K., (1968). Experimental Cell Research., 50:151-158.

Heller J (1996). Promoting the conservation and use of underutilized 
and neglected crops. 1. Physic nut Jatropha curcas L. In: International Plant Genetic Resources Institute, Rome.Pp66.

Hudzicki, J., (2009). Kirby-Bauer Disk Diffusion Susceptibility Test Protocol. American Society for Microbiology. 1-23.

Khan, S., Bakht J., and Shafi, M., (2018). Antinociceptive, antimicrobial potential and phytochemical screening of different solvent extracted samples from the stem of Acer pentapomicum. Pak. J. Pharm. Sci., 31(4): 1457-1461.

Lapornik B., Prošek M., and Wondra A.G.,(2005).Comparison of extracts prepared from plant byproducts using different solvents and extraction time. Journal of Food Engineering 71(2):214222DOI: 10.1016/j.jfoodeng.2004. 10.036

Li K.Yang W.Y, Li L., Zhang C. H., Cui Y.Z., and Sun Y.Y.,(2007). Distrubution and development strategy for Jatropha curcas L. For Stud China.,9(2):120-122

Lloyd GB, BH Mccown, (1980). Commercially feasible micropropagation of mountain laurel ( Kalmia latifolia) by use of shoot-tip culture. Proc Inter Plant Propagators Soc. 30: 421-437

Mahasneh, A.; El-Oqlah, (1999). A. Antimicrobial activity of extracts of herbal plants used in the traditional medicine in Jordan. J. Ethnopharmacol., 64, 271-276.
Malini M., Abirami G, Hemalatha V, and Annadurai

G.,

(2013).

Antimicrobial activity of ethanolic and aqueous ex-tracts of medicinal plants against wastewater pathogens. Int $\mathrm{J}$ Res Pure Appl Microbiol. ;3(2):40-42.

Makawat P. and Pankasemsuk T., (2012). Endosperm Culture of Jatropha curcas L. CMU.J.Nat.Sci. Special Issue on Agricultural \& Natural Resources. 11(1): 97-102

Mawahib E. M. EINour, Rania D. M. Albasha, and Badr Eldin A. E. Saeed, (2012): In Vitro Callus Induction of Jatropha curcas from Mature Seed in Different Auxins Concentrations International Journal of Science and Research (IJSR). 3: (6), 2319-7064 (www.ijsr.net)

Bekhit, M. A., Gomaa, E.R., Ibrahim A.l., and Nasr, K.I., (2007). In vitro studies on Ginkgo biloba L. 1Effect of explant type and growth regulators on active constituents. Az. J Pharm. Sci. 36: 167 - 181.

Modi MK, Reddy JRC, Rao BVSK, and Prasad RBN, (2006). Lipasemediated transformation of vegetable oils into biodiesel using propan-2-ol as acyl acceptor. Biotechnol. Lett. 28: 637-640.

Mubashar Nazir Mintoo; Rao D.G and Dantu P. K. (2015). In vitro shoot regeneration from leaf disc cultures Jatropha curcas, an important biofuel plant. Indian 
Journal of Plant Sciences, 4

(4):42-48

Mukherjee P., Varshney A., Johnson TS, and Jha TB, (2011). Jatropha curcas: a review on biotechnological status and challenges. Plant Biotechnol. Rep. 5: 197-215.

Murashige T., and Skooge F. (1962): A revised medium of rabid growth and bioassay with tobacco tissue cultures. Physiol. plant,15:473497.

Okoye COB, Asogwa FC., and Agbo, MO., (2013). Synergistic effect of Jatropha curcas extract and ampicillin on staphylococcus aureus and escherichia coli isolated from clinical specimens International Journal of Biological \& Pharmaceutical Research. 2013; 4(11): 816-820.

Openshaw K., (2000). A review of Jatropha Curcas. An oil plant of unfulfilled promise. Biomass Bioenergy, 19:1-15.

Pantipa N. C., Yupa P., Pimjai M., Kanokwan K., Waraporn Y., Narumon R. and Panwadee N., (2015). Regeneration of Adventitious Shoots from Callus and Leaf Explants in Jatropha curcas L. 'Phetchaburi'. Silpakorn Univ. Science \& Tech J, 9(1):28-39.

Paterson DL., (2008). Impact of antibiotic resistance in gram-negative bacilli on empirical and definitive antibiotic therapy. Clin Infect Dis. Sep 15; 47(Suppl 1):S14S20. doi: $10.1086 / 590062$.
Pei Hou, Zhang, S., Yang, L., Xu, Y., Tang L., Wang S., Tan H., and Chen F. (2006). Callus induction from Jatropha curcas endosperm and elimination of microbial contamination in culture Chinese Journal of Applied and Environmental Biology 12(2):264268.

Peirano G., (2008). Multi resistant enterobacteriaceae new threat to an old prob; expect review of antiinfective therapy. Expert Rev Anti Infect Ther. 6:657-669.

Raju AJS, Ezradanam V., (2002). Pollination ecology and fruiting behavior in a monoecious species, Jatropha curcas L. (Euphorbiaceae). Curr. Sci., 83:1395-1398.

Ruberto G., Baratta MT, Deans SG, Dorman HJ. (2000). Antioxidant and antimicrobial activity of Foeniculum vulgare and Crithmum maritimum essential oils. Planta Med. 66(8):687-693.

Sabri N.N., Elmasry S. and Khafagy S.M., (1973). Phytochemical investigation of Hyoscymus desertrum. Planta Medica. 23:49.

Sillma Rampadarath, Daneshwar Puchooa, Mala Ranghoo-Sanmukhiya (2014). Optimized in vitro plant regeneration of the biodiesel plant Jatropha curcas, the effects of using seeds at different stages of maturity as starting materials. International Journal of Plant Biology; 5:33-37.

Steel R.G.D., Torrie, J.H. and Dicky D.A., (1997). Principles and Procedures 
of Statistics, A Biometrical Approach. 3rd Edition, McGraw Hill, Inc. Book Co., New York, 352-358.

Soliman M. S., (2009). Phytochemical and pharmaceutical Studies on Jatropha curcas plant. MSc. thesis, minufiya university, Minufiya, Egypt.

Talib WH., Mahasneh AM., (2010). Antimicrobial, cytotoxicity and phytochemical screening of Jordanian plants used in traditional medicine. Molecules 15(3):1811-1824.

doi:10.3390/molecules15031811.

Warakagoda P.S., and Subasinghe S., (2009). In vitro culture establishment and shoot proliferation of Jatropha curcas L. Tropical Agricultural Research \& Extension 12(2):97-100.
Witty M., (2012). The process for 2, 3, 5 triphenyl - tetrazolium chloride synthesis, an intellectual property seized immediately after world war II. Bulletin for the History of Chemistry 37(2):91-95.

Zhong-Guang Li, Ming Gong, Shi-Zhong Yang and Wei-Biao Long, (2012). Efficient callus induction and indirect plant regeneration from various tissues of Jatropha curcas. African Journal of Biotechnology Vol. 11(31), pp. 7843-7849, Available online at http://www.academicjournals.org/ AJB.

Zhuang, X.P., Y.Y., and Yang, G.S., (2001). Extraction and determination of flavonoid in Ginkgo. Chinese Herbal Medicine .23:122-124. 